\title{
Terrorism as a Threat to the European and Global Order
}

\author{
Fatmir Rrahmanaj \\ Ministry of Foreign Affairs of Republic of Kosovo, Pristina
}

\begin{abstract}
In this paper we will discuss about terrorism as a global threat. Currently in the New World Order concepts such as terrorism has entered the field of security. Terrorism as a notion and as an activity is defined differently by different authors. As a concept, historically it has been used during the French Bourgeois Revolution, in terms of sentences imposed by the revolutionary courts against the enemies of the Republic. The word terrorism derives from the Latin word "terror" which means horror, sadness, intimidation and tremble, political violence or physical destruction of the opponent. With the end of the Cold War, the emergence of several concepts that previously did not exist, or were at a low level, changed the position and turned into one of the main threats worldwide. This was the trigger that forced states to reconsider the mechanisms of national and international security. After the events of September 11 and the attack on the twin towers in New York, it was proved that no country in the world is safe now, including those who claim to have created a modern defence system. Therefore, nowadays the challenge for countries and international organizations remains the identification of terrorists, the tools they have, where, when and how they will strike.
\end{abstract}

Keywords: terrorism, security, threat, national, international

\section{Introduction}

According to the Oxford Dictionary of Politics, terrorism is a term without any overall recognized definition by governments, analysts and academics. It is commonly used in aggravating meaning, with the purpose of describing threatening actions carried out by various sub-state groups, which are self appointed and politically motivated. ${ }^{1}$ On the other hand, terrorism is an activity, method or tactic, which as a result of a psychological process, aims to produce terror. The German and British definition of terrorism is similarly formulated. According to these definitions, terrorism is "implementation" or order for the implementation of pressure, i.e., certain physical violence against the state, public opinion, persons or their property in order to achieve certain political, religious or other ideological interests.

While the term "international terrorism" includes all forms of terrorists actions, presented as state terrorism, namely the one stimulated by the state and directed against another state, and to the various forms of cooperation among various international terrorist groups. It should be noted that international terrorism has changed from time to time. One cannot deny the fact that international terrorism has a very ancient origin, and that such a view is in contradiction to the opinion of some authors, who say that international terrorism is a product of developments in France in 1700s. ${ }^{2}$

Fatmir Rrahmanaj, M.sc., Ministry of Foreign Affairs of Republic of Kosovo.

1 Mirko Klarin, 1979, p. 24.

2 Kolë Krasniqi, International Terrorism, 2005, pp. 34-71. 


\section{Factors That Contributed to the Appearance of Terrorism}

Since the beginning of the practical use of the term terrorism, there were efforts to study the factors that had affected his appearance. However, for a long time on, these studies were conducted by scientific biased positions, based mainly on various individual or social views, without noticing the fact that terrorism appears just as complex of dialectical impacts of these two circumstances. ${ }^{3}$

Most of authors agree that the main causes of terrorism are: nationalism, ethnic problems, the large socials and economics divergences inside the country, while at international level there is considered: the growing poverty, social insecurity of smaller states, as well as conflicts over borders. ${ }^{4}$ Although there is not a stable group of factors, that promote terrorist radicalization, some are identified as more particular. Among the conditions that favour terrorism, which are recognized by the UN and the OSCE, including "long-lasted unresolved conflicts, the unveiling from the human aspects of the victims of terrorism in all its forms and manifestations, lack of rule of law, violation of human rights, discrimination based on ethnic, national and religious affiliation, political exclusion, social and economic marginalization, and misrule”. ${ }^{5}$

Presentation of terrorism and its large presence on international frameworks, comprehensiveness, intensity and diverse forms of appearance, with threats and specific crisis to the national security of states and thus the international community, have put the international community in front of great challenges. We do not aim to appreciate this social evil to contemporary civilization. Rather, our intentions were motivated for the need of the real review of this phenomenon. Nowadays it represents a serious threat and security problem of contemporary society in the national and global plan. For this reason, the study of the relevant causes to terrorism and other forms of appearance cannot be limited only to certain countries or regions, but should be studied at international level, with ongoing relationship between states and their institutions of intelligence and police security and other mechanisms including scientific institutions which can provide significant contribution to the protection of this type of security risk. ${ }^{6}$ After September 11, the US government declared open war on terrorism. But later it became clear that fighting terrorism is a very difficult and long-lasting. In the war against terrorism there can rarely be frontal war and often it is not known who to fight and from where to fight. $^{7}$

\section{International Terrorism as a Problem of World Peace and Security}

In different national debates and international forums so far, it has been noted several times, that international terrorism poses an uncontested trouble for world peace and security. Viewed globally, throughout human history, terrorism has been and remains the most common form of the development of armed conflicts. The fact that international terrorism has a symbolic number of members and used military vehicles, but with planned and well-coordinated terrorist actions, may also cause a war of wider international scale. These facts are a proof for the serious risk that this phenomenon can be for the world peace and security. Based on these facts, some authors compare international terrorist with "the global civil war". Others compare it even with "World War III". Despite this, international terrorism in all forms of meaning and its appearance has been and

\footnotetext{
${ }^{3}$ Kolë Krasniqi, Inernational Terrorism (2nd ed.), 2010, p. 29.

4 Ramo Maslesa, Security Grounds, prof. Mustafë Reçica (Trans.), p. 88.

${ }^{5}$ The UN Global Counter Terrorism Strategy, OSBE, "Ministerial Statement on Supporting the United Nations Global Counter Terrorism Strategy".

6 Ramo Maslesa, Security Grounds, prof. Mustafë Reçica (Trans.), p. 86.

7 Thomas Friedman, The World in the Age of Terrorism, 2007, p. 6.
} 
remains a strategy of violent political action in terms of changing political systems of various international subjects. At the same time, this requires to study the risk that this phenomenon represents for world peace and security. ${ }^{8}$ In this context, it is enough to remember the crime of Anders Breivik in Norway that killed 77 peoples, Al-Qaeda's attacks in London Metro, and the terrorist attack in Madrid that killed 191 peoples ${ }^{9}$, and now recently the attack in Ankara that killed nearly 100 peoples. ${ }^{10}$

These cases have prompted the international community and all other international mechanisms that cover the security, face many challenges, threats and permanent risks, which may affect negatively, unless concrete action is taken. With all the advantages that this organization has, to keep the world away from the world wars, and with its contribution to the decolonization of many countries, the creation of new states and many roles and uncontested contributions towards the peace settlement in the world, this phenomenon is somehow causing many concerns. ${ }^{11}$ Therefore, the UN must adopt a comprehensive strategy for banning terrorist funding, and finance marginalization of suspicious groups, which through allegedly religious stocks and on behalf of religion abuse with the human rights, thus destroying humans' destinies. Facing this challenge the UN should assist countries more, in fighting terrorism expanding their competencies of relevant departments which are engaged in the fight against terrorism. Although the UN has issued Resolution 1566, prohibiting the financing of terrorist activities, in 2004, it needs to re-engage more in respecting or the obligation to respecting by the respective states of the Geneva Conventions and its Protocols. ${ }^{12}$

\section{Protection Undertaken Measures Against Terrorism}

Prevention of terrorism should be based on a legal framework such as the Council of Europe, Convention for the Prevention of Terrorism ${ }^{13}$, since it has been evidenced as a good international practice. ${ }^{14}$ The convention defines the criminal acts and recruitment for terrorist purposes. Resolution of the Security Council of the UN, No. 1373, obliges states to stop the recruitment of terrorists, while Resolution 1624 (2005) requires from states to prohibit the promotion of committing terrorist acts, by law. ${ }^{15}$ To be in accordance with international standards, criminalisation of terrorist incitement must be accompanied by appropriate standards, in accordance with the principle of legality and in support of the fundamental rights, including freedom of expression. ${ }^{16}$

On the other hand the investigation and prosecution of criminal cases related to terrorism, including the promotion and recruitment for terrorist purposes, should be based on specific facts, should ensure a fair process and trial, as well as to comply with the absolute prohibition of torture or any other cruel, inhuman or degrading treatment or punishment, with the right to life and the right to freedom and security. ${ }^{17}$ However, the nature of

8 Jenkins, B. M. (1975). International Terrorism: A New Mode of Conflict, pp. 105-108.

9 See from http://www.telegrafi.com/lajme/keto-jane-sulmet-me-te-frikshme-terroriste-ne-evrope-video-4-23062.html.

${ }^{10}$ See from http://www.albeu.com/video-lajme/rriten-bilanci-86-te-vdekur-e-186-te-plagosur-nga-sulmet-terroriste-/216133.

11 Joshua, S. Goldstein, International Relations, 2003, p. 233.

12 The UN-Challenges, Risks and Security Threats. See from http://www.albaniapress.com/lajme/9546/.

13 Council of Europe, Convention for the Prevention of Terrorism, CETS nr. 196, 16 May, 2005, http://conventions.coe.int/Treaty/en/Treaties/Html/196.htm.

${ }_{14}$ Ten areas of best practices in countering terrorism, see also: The UN Security Council Resolution 1624 (2005) Compilation of Internal Good Practices, Codes and Standards, the Department of Executive Committee against Terrorism.

15 Resolution nr. 1624 (2005) adopted by the UN Security Council at 5261 meeting, on 14 September 2005, (S/RES/1624 (2005).

${ }^{16}$ See section 2.4.2 of the guideline from http://www.un.org/press/en/2005/sc8496.doc.htm.

17 See Human Rights in Counterterrorism Investigations: A Practical Manual for Law Enforcement Officers, from http://www.osce.org/odihr/108930. 
terrorism as a serious crime is such that the police or other state competent agencies must use special techniques of investigation, for example the use of undercover agents, surveillance and interception of communications. Special techniques of investigation include serious intrusion in aspects of human rights, particularly the rights to a fair trial and privacy. Consequently, the use of these techniques should be limited to serious cases and proportionate to the seriousness of the matter under investigation and based on laws that ascertain and clearly define mechanisms for prior authorization, monitoring, review and accountability in the light of human rights, especially the right to a fair trial and the rule of law. ${ }^{18}$ It has conditioned a new approach to the creation and planning of an overall strategy aimed at efficient prevention of acts of terrorism. There are serious weaknesses in the field of legislation and concessions from authorities and security services such as: organizational, professional, operational, materials etc, and most notably there was a lack of concrete activities to prevent terrorist.

Given this, some countries (US, UK, France, Germany, Italy, Belgium, etc.) have undertaken a number of measures including legislation, information, security and the police as terrorism poses a serious threat to the national security. Special Forces to fight against terrorist have been formed through the adoption of new laws and amendments to existing ones, while in the intelligence and security services (counter-intelligence) departments or services for counterterrorism have been formed, by collecting interesting information notes in a planned way, on purposes and activities of terrorist organizations. Based on this information and evaluating the authenticity there are planned concrete operations in which they engage the security mechanisms that are in accordance with the constitution and the law. For this reason we can emphasize that the declarations and conventions to which we referred earlier and which were approved at the global level, as well as from international organizations-Interpol, have not stopped the growing trend of this kind of violence as the worst example of violent murders in history. ${ }^{19}$

\section{Conclusion}

In conclusion we can say that terrorism consistently follows certain political processes, which appear through various forms of violence, and depending on generators it intends to destabilize the fundamental values of any society. Since it has to do with the current security problems, we cannot pinpoint it in a particular country or in a wider territory. It has to do with a phenomenon related to security, which international community is facing consistently.

All forms and modes of terrorism appearance have a multidimensional, destructive and unknown character, especially if we consider its modern methods and views of his actions that have taken serious political connotations, recently. In particular, the bearers of terrorism nowadays use the most modern technical and technological means, where professionalism, globalization, and cooperation between terrorist organizations are evident with the aim of committing terrorist acts by using biological, chemical, nuclear and other means.

From the above mentioned factors, we came to the conclusion that the contrary interests between countries, and the establishment of various protection mechanisms for security, present divergent approach in solving the problem of terrorism at the international level. However, this kind of approach is affected by attitudes and

\footnotetext{
${ }^{18}$ See Council of Europe, Recommendation (2005) 10 of the Council of Europe Committee of Ministers on "The Special investigation Techniques" related to the serious crimes, including acts of terrorism, Strasburg, 20 April, 2005 from https://wcd.coe.int/ViewDoc.jspd=849269\&Site=COE.

19 Ramo Maslesa, Security Grounds, prof. Mustafë Reçica, (Trans.), pp. 87-88.
} 
political interests of certain states, namely by the global policy strategy, especially in the field of foreign policy, because the process of establishing the framework, global policies which should involve running for a more stable autonomy, for a secure political subjectivity of states, overcoming numerous contradictions, etc.

As we said above in this paper, the main concern of international mechanisms such as the UN in global governance is the involvement of the states themselves in terrorist acts. The terrorism prompted by state is simply called an undeclared form of war with a low intensity, between sovereign states.

Recently, many countries with different ideological persuasion have been involved in this, which in some cases has not prevented them to incriminate the others, for the same actions. An interesting principle is highlighted in the Oxford dictionary: "the individual, who for a state is a terrorist, at the same time, is a freedom fighter to another state”. ${ }^{20}$

\section{References}

Brian, M. J. (1975). International terrorism: A new mode of conflict. Los Angeles: Crescent Publications.

Friedman, T. (2007). The world in the age of terrorism. Tiranë.

Goldstein Joshua, S. (2003). International relations. Tiranë: Dituria.

Iain Mc, L. (1996). Oxford dictionary of politics. Tiranë: International Center of Culture.

Krasniqi, K. (2005). International terrorism. Tiranë: Uegen.

Klarin, M. (1979). Terorizam. Beograd.

Krasniqi, K. (2010). International terrorism (2nd ed.). Prishtinë.

Maslesa, R. (n.d.). Security grounds (prof. Mustafë Reçica, Trans.).

OSCE Organization for Secority and Co-oporation in Europe. The UN Global Counter Terrorism Strategy. "Ministerial Statement on Supporting the United Nations Global Counter Terrorism Strategy”.

The UN-Challenges, risks and security threats. Retrieved from http://www.albaniapress.com/lajme/9546/

Council of Europe. Convention for the Prevention of Terrorism, CETS nr. 196. Retrieved 16 May, 2005 from http://www.coe.int/en/web/conventions/full-list/-/conventions/treaty/196

The UN Security Council Resolution 1624 (2005) Compilation of Internal Good Practices, Codes and Standards, Rezolutën e Këshillit të Sigurimit nr. 1624 (2005). The Department of Executive Committee against Terrorism.

Resolution nr. 1624 (2005). The UN Security Council at 5261 meeting, on 14 September 2005. (S/RES/1624 (2005)

Human rights in counterterrorism investigations: A practical manual for law enforcement officers. (2013). Warsaw: OSBE/ODIHR. Retrieved from http://www.osce.org/odihr/108930

Council of Europe. (2005, April 20). Prevention of terrorism and war against extremism and radicalism favoring violent terrorism. "The Special investigation Techniques" related to the serious crimes, including acts of terrorism, Strasburg, retrieved from https://wcd.coe.int/ViewDoc.jspd=849269\&Site=COE

http://www.telegrafi.com/lajme/keto-jane-sulmet-me-te-frikshme-terroriste-ne-evrope-video-4-23062

http://www.albeu.com/video-lajme/rriten-bilanci-86-te-vdekur-e-186-te-plagosur-nga-sulmet-terroriste-/216133

${ }^{20}$ Iain Mc Lean, Oxford Dictionary of Politics, p. 595. 